\title{
MacDermott Lecture 2008: Litigating international disputes - the work of the International Court of Justice in a changing world
}

\author{
GiVEN AT QueEn's UNIVERSITY BeLFAST ON 16 ApRIL 2008 By \\ H E JUdGe Rosalyn Higgins \\ President of the INTERNATIONAL Court of Justice
}

The MacDermott Lecture is delivered annually at Queen's University Belfast. Previous speakers in recent years have included Lord Hutton and Rabinder Singh. Lord John MacDermott studied at Queen's in the early years of the twentieth century and went on to pursue a distinguished political and legal career, later returning to Queen's to teach and to hold the position of pro-vice chancellor. He was Lord Chief Justice of Northern Ireland from 1951 to 1971.

Tam very pleased to deliver this MacDermott lecture, named for Lord MacDermott who 1 presided over the Courts of Northern Ireland for two decades. I also take this opportunity to offer my congratulations to Queen's University Belfast on the occasion of its centenary. I have so admired the role of the University generally, and its Law Department specifically, in the difficult times of the recent past, and it gives me a very real pleasure to be here among you.

The International Court of Justice (ICJ) is the principal judicial organ of the United Nations and one of its main organs, along with the General Assembly, Security Council, Secretariat and the Economic and Social Council. We share with the other UN organs the purpose stated in Art. 1 of the Charter: the maintenance of international peace and security. Our particular contribution to this goal is the judicial settlement of international disputes in conformity with the principles of justice and international law.

We have a dual role: to settle in accordance with international law the legal disputes submitted to the court by states, and to give advisory opinions on legal questions referred to the court by certain organs of the United Nations and sixteen duly authorised specialised agencies. The ICJ was established sixty-two years ago at the end of the Second World War. It was the successor to the Permanent Court of International Justice that was functioning at the time of the League of Nations.

In its early years the International Court had to operate against the negative background of the Cold War. There was a multi-polar international system of power, on which was superimposed the great doctrinal hostilities of capitalism and Marxism. These factors necessarily constrained the overall contribution that the court could make. It had a small, but meaningful docket during this period. A different challenge then faced the court in the 1970 s with the emergence, a few years earlier, from colonialism, of new independent states. These states needed reassurance that international law was a law relevant to their interests as well as to the interests of the so-called First World. At the same time, the longer established states wanted to feel secure that international law would continue to provide a core stability 
that would be applicable to all nations. During this era, the court's caseload was relatively light and it entered a dormant period.

This all changed in the late 1980s, with the end of the Cold War and greatly improved East-West relations. There was new enthusiasm for third-party dispute settlement. Of the ninety-five judgments the court has handed down in its sixty years of existence, one half have been delivered in the past twenty years.

Recent years have been characterised by the phenomenon of globalisation. States are no longer the only actors in international law: individuals, corporations, and nongovernmental organisations are now regarded as having both rights and responsibilities under international law. The widening reach of technology and the constant flows of information, currency, arms, narcotics and diseases have rendered national borders porous. International law has expanded to cover entirely new topics, such as space, human rights, trade law and environmental law.

The International Court lives in the real world and these changes in the world have their impact on us, too. Today, I will discuss three key features of the litigation of international disputes before the International Court of Justice: the identity of the parties, the subjectmatter of the disputes, and issues of procedure.

\section{Identity of the parties}

I begin with some words on how our changing world has had implications for who litigates before us today.

The International Court is being more widely used than ever before, both in terms of the number of parties submitting cases to us and the regions of the world represented by those parties. Seventy-nine states have engaged in court proceedings in the past decade. They have participated as applicants and respondents in contentious cases or have submitted written or oral statements in advisory opinion proceedings. This has naturally had an impact on the workload of the court.

From 2002 to the end of 2005, the court decided eighteen cases. Over the same period, eight new contentious cases were filed with the court, along with one request for an Advisory Opinion. In 2006, the court disposed of one case (Congo v Rwanda) and continued deliberations in three other cases. Three new contentious cases were filed with the court in 2006 (one of which was later withdrawn), as well as two requests for the indication of provisional measures. Such requests have priority over all other cases and were rapidly answered by the court.

In 2007, we had our most productive year since the court was established. We issued two judgments on the merits, two judgments on preliminary objections to jurisdiction and an order regarding provisional measures. These cases have involved states from Latin America, Europe and Africa.

Thus far this year, we have held hearings in one case between Djibouti and France and two new contentious cases have been filed with the court: one between Peru and Chile concerning the delimitation of their maritime zones; and one between Ecuador and Colombia on the alleged aerial spraying by Colombia of toxic herbicides over Ecuadorian territory in connection with opium and coca plantations. Our current docket stands at thirteen cases. You will understand that when states litigate, we are speaking of mega-cases, usually larger in terms of pleadings than even the most major commercial cases.

Our cases come from all over the world: our docket presently contains five cases between Latin American states, three between European states, two between African states, one between Asian states and two of an intercontinental character. Interestingly, 2006 was 
an "African year" for the Court with cases between the Democratic Republic of the Congo (DRC) and Uganda, the DRC and Rwanda, and Guinea and the DRC. The following year, 2007, was a "Latin American and Asian year" with cases between Nicaragua and Honduras, Nicaragua and Colombia, and Malaysia and Singapore. This year, 2008, is shaping up to be a truly international year with both an intercontinental case, Djibouti v France, and two Eastern European cases, Croatia v Serbia and Montenegro and Romania v Ukraine.

Over the past few decades, the court has been gratified to see the trust placed by Asia and Africa - as well as Latin America - in third-party dispute settlement in general, and in the resolution of interstate disputes by the International Court in particular.

The past decade, in particular, has seen a dramatic increase in the number of cases brought to the court by African States. From 1960 to 1980, only five cases came to the International Court involving African countries. In the past decade, eleven such cases more than double in half the time - have come to the court. And in very recent times - just the past three years - eight Latin American states have submitted their disputes to the court for resolution. Of the current docket, more than one-third of the cases involve Latin American states. There seems no particular reason why this should be so.

That states from all regions of the world are now ready to appear before the International Court is warmly to be welcomed. It confirms that the International Court is truly the court of the United Nations as a whole.

Within this general trend towards wider use of the court, there are several noticeable tendencies in terms of how states are choosing to come to the court. The Statute of the Court is annexed to the Charter and each of the 192 member states of the United Nations is thereby a party to the Statute. That constitutes an entitlement to use the court. But states cannot be compelled to use the court - consent is required to be a party to a case. There are several ways in which that consent can be expressed.

I refer first to the so-called "optional clause", by which a state formally notifies to the Secretary General of the United Nations its agreement to be taken to court by any other state accepting the same commitment. In recent times, a number of states have taken this route: of the sixty-five declarations accepting the optional clause, one-third have been deposited in the past fifteen years.

Today, approximately 300 treaties refer to the court in relation to the settlement of disputes arising from their application or interpretation and there has been a distinct trend for states to withdraw reservations they made to such treaties in earlier years. Last year, Russia passed legislation removing reservations to the ICJ's jurisdiction in six international treaties against terrorism. The court today receives many of its cases based on such jurisdictional provisions in treaties. For example, between 1998 and 2003, three cases were brought to the court by Paraguay, Germany and Mexico, claiming the United States had violated the right of their arrested nationals to consular notification. Jurisdiction was based on a clause contained in the Vienna Convention on Consular Relations.

Two states may have reached the end of the road in trying to settle a dispute diplomatically and may jointly decide to let the court resolve the matter. Two cases from Asia recently came to the court in this manner: Sovereignty over Pulau Ligitan and Pulau Sipadan (Indonesia/Malaysia), which was decided in 2002, and Sovereignty over Pedra Branca/Pulau Batu Puteh, Middle Rocks and South Ledge (Malaysia/Singapore), in which hearings were held in November 2007. That case is currently under deliberation. Such cases have been coming in from every corner of the world: Benin/Niger, Botswana/Namibia; Hungary/Slovakia. This would seem to show both an increased readiness on the part of states everywhere to have recourse to a judicial resolution of their disputes, and a continuing global confidence in the ICJ. 
The final method of consenting to the court's jurisdiction is forum prorogatum whereby one state brings a case, simply inviting the intended respondent to accept the court's jurisdiction for the purpose of the case. Since 1978, when this method of consent was included in the Rules of Court, there have only been two occasions that it was been used. It is striking that both instances have taken place in the past three years and both involved France and an African State. In 2003, France accepted the jurisdiction of the court with respect to the case concerning Certain Criminal Proceedings in France brought by the Republic of the Congo. And in 2006, France consented to the court's jurisdiction in a case brought by Djibouti, concerning Certain Questions of Mutual Assistance in Criminal Matters. That case is also under deliberation at the moment.

You may be interested to know that the International Court enjoys a very high rate of compliance with its judgments from all kinds of states in all types of cases; a rate that compares favourably with that of any national court. It is to be hoped that this is a result of the quality and impartiality of the judgments, but also due to the court's special status within the UN. No member state wants to sit in the General Assembly or Security Council, knowing that it is violating a decision issued by another main organ of the UN, which is binding upon it. That is why even in cases that have been bitterly fought and have a volatile history, we have seen the commitment to implement the judgment once it is given.

\section{Subject matter of the disputes}

In our contemporary world we are finding that not only do the cases come in from all the regions of the globe, but they also address all types of legal problems.

States continue to bring the classical types of disputes to the court - many years after the era of decolonisation, we continue to have a steady stream of territorial and maritime border disputes submitted to the court for resolution. At the same time, cases on cutting-edge topics of international law are also being brought by parties seeking judgments on disputes concerning the use of force, immunities, or mutual legal assistance in criminal matters.

To set the scene, let me give you a few examples that show how at one and the same time we continue to deal with classical topics but also increasingly respond to current preoccupations.

This "classic topic" example is from 1994, when Cameroon brought a case against Nigeria concerning sovereignty over $1800 \mathrm{~km}$ of land frontier, the vast Bakassi Peninsula, and the entire maritime delimitation offshore. As you can imagine the political and economic issues at stake for both of the states were enormous. The court's judgment delimited the long land frontier, held that the Bakassi Peninsula belonged to Cameroon, and delimited the respective maritime spaces. With some assistance from Kofi Annan while he was Secretary General, the court's judgment was implemented step by step. Generally, good relations have resumed between the two states and the military have stepped back.

We continue to receive cases concerning territorial and maritime matters. In the past year alone, the court has heard three such cases. A dispute between Malaysia and Singapore concerning the sovereignty over certain maritime features is currently under deliberation. Then there are two cases brought by Nicaragua against Honduras and Colombia. The court delivered its judgment in the Nicaragua v Honduras case last December 2007. The dispute concerned the maritime boundary between the two countries as well as sovereignty over four cays in the Caribbean Sea. The court carefully examined the evidence, including the circumstances of an Award of the King of Spain made in 1906, diplomatic exchanges between the various governments of Nicaragua and Honduras, and whether there had been an actual exercise or display of authorities by the two states over the islands in dispute. The 
court decided the four cays belonged to Honduras and a bisector line should serve as the maritime boundary.

We dealt in 2007 with the jurisdictional phase of a case involving Nicaragua and Colombia, which also concerned title over islands and the location of the maritime frontier. The parties are now proceeding with their written pleadings.

Later in 2008, we will hold hearings in a case between Romania and Ukraine concerning maritime delimitation in the Black Sea. As you can see, disputes involving classical territorial and maritime issues continue to occupy an important place on the court's docket and come from all over the world.

But we inevitably find, in the greater readiness that exists today to have disputes resolved by judicial means, that we are also deciding cases that involve the use of force and violations of human rights law and humanitarian law.

In 2005, the court issued a judgment in the case concerning Armed Activities on the Territory of the Congo (Democratic Republic of the Congo v Uganda). That case involved very grave allegations relating, inter alia, to the unlawful use of force, violation of territorial sovereignty, occupation, human rights and humanitarian law violations, as well as the illegal exploitation of natural resources. This was by no means an easy case for the court. In the first place, when the deliberations on the merits started, the armed conflict was not entirely settled on the ground. Moreover, the number of specific violations alleged by the parties and the amount and variety of material submitted in support of these allegations were unprecedented.

In its judgment of 19 December 2005, the court ruled favourably on several of the Congo's claims although it did follow Uganda on one of its counter-claims. The court's detailed and objective findings helped resolve at least some of the intractable issues of fact and law in the Great Lakes region.

I am also going to have to say some words on the Genocide case between Bosnia and Herzegovina and what was then known as Serbia and Montenegro. The case concerned what is widely regarded as the most serious violation of human rights - the commission of genocide. Given that this was the first legal case in which allegations of genocide had been made by one state against another, the International Court was acutely sensitive to its responsibilities. The court - as it always does - meticulously applied the law to each and every one of the issues before it.

In its judgment, delivered in February 2007, the court found it clearly established that massive killings and other atrocities were perpetrated during the conflict throughout the territory of Bosnia and Herzegovina, but the evidence had not convincingly shown that those acts in these many locations were committed with the specific intent required for the crime of genocide, that is, the intent to destroy, in whole or in part, the group as such. However, it did find that the killings in Srebrenica in July 1995 were committed with the specific intent to destroy, in part, the group of the Muslims of Bosnia and Herzegovina in that area and that what happened there was indeed genocide.

The court then turned to the question of Serbia's responsibility for such genocide in Srebrenica. It found that all the evidence indicated that the decision to kill the adult male population of the Muslim community in Srebrenica was taken by some members of the VRS (army of the Republika Srpska) Main Staff. The army of Serbia and Montenegro was not proved to have itself been actively engaged, nor was there an "evidence trail" to show the orders came from Belgrade.

Nonetheless, the court found that Serbia had violated its obligation to prevent the Srebrenica genocide. This obligation is contained in Art. 1 of the Genocide Convention. 
It requires states that are aware, or should normally have been aware, of the serious danger that acts of genocide would be committed, to employ all means reasonably available to them to prevent genocide. Serbia could, and should, have acted to prevent the genocide, but did nothing.

The court further held that the respondent had violated its obligation to punish the perpetrators of genocide, including by failing to cooperate fully with the International Criminal Tribunal for the Former Yugoslavia (ICTY) with respect to the handing over for trial of General Ratko Mladić

The case has generated considerable publicity. The concept of genocide is often used loosely and inaccurately, not only by victims but also by those in authority. It must be welcome that today politicians and others are so committed to the idea that all efforts must be mobilised against the occurrence of genocide. But this phenomenon, so laudable in principle, has brought with it its own problems, too. We see governments passing legislation instructing citizens as to what events in history they may not deny were "genocide"; we see art and other exhibitions being threatened or closed down because of angry responses to certain events being classified (or not classified) as "genocide". We see confident assertions by press, politicians, yes, and victims too, as to this or that being "genocide". We are at risk of losing the idea of genocide as a concept of international law. Those who invoke it know little or nothing of the Genocide Convention, in which genocide and related offences are meticulously defined.

It seems generally appreciated that other concepts of international law most usually require legal training to be appropriately invoked: and when they are invoked in the context of international litigation, it might be thought that there is a need for these legal definitions to be tested against evidence proven in accordance with relevant standards of proof. Not so, apparently, with genocide, which has become a term of general use, in much the same way that, for example, the concept of "aggression" has. To politicians, the media and - more understandably - victims genocide has come to be synonymous with large-scale slaughter of civilians. That is not, of course, what genocide means in law. Article 2 of the Genocide Convention defines genocide very precisely as certain acts "committed with intent to destroy, in whole or in part, a national, ethnical, racial or religious group, as such" - within that definition, there are many, many complicated elements of law and fact always to be addressed.

The judgment of the court in the Bosnia v Serbia case sought not only to answer the claims before it, but also systematically to elaborate and explain each and every element in the Genocide Convention, believing this latter task is also a necessary contribution to clarity and understanding. The genocide claims that Croatia has started against Serbia and Montenegro remain on our docket, and the case is scheduled to be heard in May 2008 on preliminary objections to jurisdiction.

Another contemporary type of dispute that has been appearing on the court's docket arises from the increasing tendency for states to assert jurisdiction over heinous crimes committed against their nationals abroad, or indeed to assert a more general jurisdiction over these things. The corollary is that in so far as high state officials or even the head of state themself are implicated in these charges, state immunity is taking on a renewed and lively importance.

There has been an outburst of judicial activity in national courts on these topics in the past few years - for example, the Pinochet cases in the United Kingdom and the Guatemala Genocide case in Spain. The "International Law in Domestic Courts" database, covering the period from 2000 to the present day, contains fifty-nine cases concerning immunities in 
twenty jurisdictions, ranging from Botswana to Finland and Sierra Leone. These trends have been having a knock-on effect in international courts.

At the International Court, questions of universal jurisdiction and immunities of highlevel government officials were raised in the Arrest Warrant case of 2002. An international arrest warrant had been issued by a Belgian investigating judge against Mr Yerodia, the Minister for Foreign Affairs of the Congo. It sought his provisional detention pending a request for extradition to Belgium for alleged crimes constituting "serious violations of international humanitarian law". Mr Yerodia was accused of having made various speeches directly inciting racial hatred before he became Foreign Minister (at which later time the arrest warrant was issued). By the time the case came to court, Mr Yerodia had ceased to be Foreign Minister and had become Minister of Education. The International Court stated that the immunities of Ministers for Foreign Affairs were not granted for their personal benefit, "but to ensure the effective performance of their functions on behalf of their respective States". Freedom to travel and freedom of communication were important, as was the fact that a foreign minister "occupies a position such that, like the Head of State or the Head of Government, he or she is recognized under international law as representative of the State solely by virtue of his or her office". This immunity protected the individual concerned against any act of authority of another state "which would hinder him or her in the performance of his or her duties". The court ordered that the warrant be annulled and Belgium immediately complied.

Immunity issues have again been raised before the International Court in the Djibouti v France case; this time in relation to the State Prosecutor and the Head of National Security.

The rising interest among states in the investigation and prosecution of individuals outside of national borders for crimes such as crimes against humanity, torture, terrorism, and trafficking has resulted in the International Court receiving some cases concerning questions of mutual legal assistance. The current proceedings instituted by Djibouti against France are a good example. Djibouti is claiming that the refusal of French authorities to execute an international letter rogatory regarding the transmission of the record relating to a certain murder investigation violates obligations under treaties in force between the two countries. A judgment in this case will be rendered before long. In the pending case concerning Certain Criminal Proceedings in France, the Republic of the Congo seeks the annulment of the investigation and prosecution measures taken by French judicial authorities in response to a complaint of crimes against humanity and torture filed against, inter alia, the President of the Congo, the Congolese Minister of the Interior and the Inspector General of the Congolese Army.

I should also refer to the frequent recourse to the court for provisional measures. (This is the term used by the court for injunctions.) Whereas between 1985 and 1995 only seven requests for provisional measures were made, over the past decade the court has been asked nineteen times to exercise its power to issue provisional measures to preserve the respective rights of parties to a case. It granted the measures in fifteen of those instances. In 2001, the court ruled that provisional measures were indeed binding obligations. This phenomenon is raising a cluster of important legal issues that will surely merit our particular attention in the period ahead.

\section{Procedural issues}

I am now going to say a few words on procedural matters. The proceedings before the International Court include a written phase, in which the parties file and exchange pleadings, and an oral phase, consisting of public hearings at which agents and counsel 
address the court. As the court has two official languages (English and French), everything written or said in one language is translated into the other.

As I mentioned earlier, all the cases that come to the ICJ are massive. Parties often raise complex jurisdictional questions as well as alleging a number of specific violations of international law on the merits. In recent cases, they have been submitting hundreds of pieces of evidence as annexes to their written pleadings. The Bosnia and Herzegovina v Serbia and Montenegro case, for example, required public hearings that stretched over two-and-a-half months covering both jurisdictional and merits issues. The court sifted through vast amounts of documentary and audiovisual evidence and heard witness testimony in the courtroom. Moreover, the court paid careful attention to the findings of the ICTY, which necessitated reading and analysing dozens of decisions issued by that tribunal over the past decade. The judgment ultimately numbered 170 pages, with about one-third devoted to analysing the evidence and making detailed findings as to whether alleged atrocities occurred in specific locations and, if so, whether there was the specific intent on the part of the perpetrators to destroy in whole or in part the protected group that would classify them as genocide.

We work under the Statute of the Court (which is annexed to the UN Charter), the Rules of Procedure and the Practice Directions, which we introduced a few years ago to give us greater flexibility in the handling of litigation. We have Practice Directions aimed at accelerating proceedings on preliminary objections (Practice Direction V), encouraging succinct oral statements (Practice Direction VI) and controlling the submission of new documents after the closure of written proceedings (Practice Direction IX).

The Rules and Practice Directions can be amended by the court, but the Statute can only be amended in the same way as the UN Charter, that is, by a vote of two-thirds of the members of the General Assembly and ratified in accordance with their respective constitutional processes by two-thirds of the members of the UN, including all the permanent members of the Security Council. The Statute provides in Art. 34 that only states may be parties in cases before the court. We cannot change that, but we can and do amend our Rules and Practice Directions to allow for non-state actors - who are now such important players on the international stage - to have a voice in relevant proceedings. In 2005, the court adopted amendments to Art. 43 of its Rules to establish a mechanism to enable international organisations to submit observations on conventions that they are party to that are at issue in a case before the court. Practice Direction XII was introduced to allow states to refer to written statements or documents submitted by international NGOs in advisory proceedings.

Occasionally the court faces a situation that is right at the margin of its Statute and Rules. During the advisory proceedings on the Legal Consequences of the Construction of a Wall in the Occupied Palestinian Territory, the court faced the problem of assimilating Palestine's position with that of a state or an international organisation. The hurdle of participating in the proceedings before the court was overcome due to the General Assembly resolution requesting the opinion, the report of the Secretary General transmitted to the court with the request, Palestine's special status of observer at the UN, and the fact that it was the cosponsor of the draft resolution requesting the advisory opinion. Palestine was therefore permitted to submit a written statement and take part in the hearings.

What has greatly changed in today's world is that there are now many litigation opportunities for states. Until the 1960s, the International Court stood almost alone as a vehicle for resolving international law disputes. But the past two decades, in particular, have seen the burgeoning of international courts and tribunals equipped to deal with disputes 
that might arise under the growing reach of international law. The International Court is now joined by regional human rights courts, by international criminal courts and tribunals, by courts which are part of treaty systems for regional economic integration, by a Tribunal for the Law of the Sea, by decision-making panels on trade - and very many more.

The international criminal courts and tribunals are not interstate courts. Rather, they are designed to deal with the accountability of individuals for war crimes, crimes against humanity and genocide. Nonetheless, these courts may apply the same law as the ICJ, in particular on the use of force, the conduct of hostilities and the meaning of international crimes, and they can and do end up analysing the same situations (for example, the Balkans, Congo and Uganda).

There are fears in certain quarters of international law being "fragmented" by conflicting decisions of international courts and tribunals operating in a horizontal, decentralised environment. But the reality suggests that such fears are exaggerated. What is striking is not the differences between the international courts and tribunals, but the efforts made at compliance with general international law. We see this in a variety of areas where more than one judicial body is operating, such as the law of the sea, human rights law and environmental law. The ICJ enjoys cordial relationships with other international courts. We have an informal system of exchange whereby judges at international courts and tribunals receive relevant excerpts of our cases that address legal questions of particular interest, and vice versa. And the ICJ has been hosting inter-court seminars to discuss legal topics of mutual interest.

\section{Conclusion}

As a judicial institution, the International Court must provide that core predictability that distinguishes law from politics. But we have to do this in a way that is responsive to the changes in the world around us, such as the diversity of parties who appear before the court, the wide array of subject-matter involved in the disputes, the dramatic growth of other international courts and tribunals, and the fact-intensive nature of recent cases. Not all of these phenomena may be visible when reading our judgments, but they are very much in the minds of the judges.

The International Court has been actively engaged with these changes, adjusting its rules and working methods where necessary. In the past, there was a problem with long gaps between the close of the written proceedings and the opening of the oral hearings; a backlog had built up. In 2007, we eliminated this backlog and also had our most productive year on record. And now four months into 2008, we are on schedule for another busy year fulfilling our role as the principal judicial organ of the United Nations. 
